\title{
Current State and Perspectives of Securitization Processes in the Russian Federation
}

\author{
Koniagina Mariia Nikolaevna ${ }^{\dagger}$ \\ North-West Institute of Management, Russian Academy of National Economy and Public Administration under the President of the Russian \\ Federation, St Petersburg, Russia, 197376 Pesochnaya Embankment, 4, St Petersburg/ Russia
}

\begin{tabular}{l}
\hline ARTICLE INFO \\
\hline Article History \\
Received 25 July $2020 ;$ \\
Accepted 26 September \\
2020 \\
\hline JEL Classifications
\end{tabular}

G18, G21, G23

Keywords: Securitized assets; Mortgage; Mortgage bonds; Mortgage loan; Commercial bank; Securitization \author{
ABSTRACT

Purpose: \\ The study is aimed not only at determining the current state of the bank asset securitization \\ market but also at developing methods and ways to improve the processes of bank asset
} securitization in Russia.

Design/methodology/approach:

The article presents the results of a survey of Russian market securitization over the last 10 years, where the author separately considers mortgage and non-mortgage securitization, conducts a discrete analysis of regulatory changes in securitization, and identifies the main problems in the development of this important economic process and the issues that have remained unresolved during the decade. The main methods of study chosen by the author are systematization, generalization and econometric analysis.

Finding:

The author has demonstrated that there is a strong inverse relationship between the mortgage lending volume and the interest rate, and has built a linear function of the estimated mortgage lending volume. The excess in the real mortgage lending volume over the estimates confirms that the current state policy, including state support and reduction of the Central Bank key rate, in the sphere of mortgage lending is indeed stimulating.

Research limitations/implications:

The development of securitization in Russia has been constrained not only by sanctions and bureaucratic inconsistencies in the requirements set for securitized assets, but also by delay in the access of the official bodies such as the Federal Service for State Registration, the Cadastre, and Cartography ("Rosreestre") to modern technologies, as well as by the insecurity and distrust of digital financial service technologies.Quite different conclusions follow from the analysis of non-mortgage securitization, where the author supports and develops critical remarks expressed by other researchers in previous years.

Originality/value:

The survey results not only show the achievements of mortgage lending in Russia in recent years, but also provide valuable recommendations to help support the positive dynamics of mortgage lending and securitization development in the Russian Federation.

\footnotetext{
1. Introduction

The growing demand for credit resources in the real sector of the Russian economy encourages the national banking system to seek long-term financing and look for effective instruments for refinancing loans. In the late 1980s, a new way of attracting long-term financing, based on attracting any assets that create a stable cash flow, was introduced into the global financial system (Burkova, 2014). World practice in recent decades shows that securitization is widely used in financial markets to attract additional financing, meet capital adequacy standards, maintain liquidity, diversify assets and minimize risks.

Securitization is an evolving complex innovative process which has good prospects for implementation and development in the practice of Russian banks. This is an effective way of raising funds as it provides access to almost unlimited resources both in Russia and abroad, bypassing sanction barriers. Securitization allows the credit institution to obtain liquid funds without losing the efficiency of active operations. It all makes the study of the current conditions and prospects of the bank asset securitization market in Russia especially relevant.
} 
The subject of the study is bank asset securitization in Russia and the relations that arise between the parties in the course of this process. The study is aimed not only at determining the current state of the bank asset securitization market but also at developing methods and ways to improve the processes of bank asset securitization in Russia. To achieve these goals, the author has 1) analyzed and evaluated the Russian securitization market; 2) highlighted problems and prospects of securitization development in Russia; 3) proposed a number of measures to solve the current problems in the process of bank securitization in Russia.

\section{Literature Review}

Quite a number of works in the economic literature are devoted to the problems of securitization. The theoretical basis of this research consists of works of Russian and foreign scientists on securitization, financial management, investment operations and regulation of operations with derivatives. It is necessary to mention the works of E.R. Yescombe (Yescombe, 2013), T. Belikov (Belikov, 2009), H.P. Baer (Baer, 2007), T.S. Kolmykova (Kolmykova, 2013) and some other authors. Detailed theoretical and methodological provisions on securitization are presented in the works of N.V. Aleksandrov (Alexandrov, 2007), I.I. Guliyev (Guliyev, 2014), L.N. Drobyshevskaya and T.V. Koneva (Drobyshevskaya, Koneva, 2013), L.P. Harchenko (Harchenko, 2017).

This research also takes into consideration the works devoted to the general issues of securitization in Russia: V.S. Aksenov and P.S. Golikov (Aksenov, etc., 2013), M.A. Denisov (Denisov, 2016), V.E. Krolivetskaya (Krolivetskaya, 2019), O.V. Khmyz (Khmyz, Alekseeva, 2018), I.M. Golaido and Tsvyrko, A.A. (Golaido, etc., 2019). As mortgage loans constitute the largest share of securitization in Russia, it is most interesting to provide a retrospective comparison of the results and conclusions presented in the publications of E. Davidson (Davidson, etc., 2007) and Y.A. Burkova (Burkova, 2014). The author also resorts to the results of the study on housing and communal services (Vasilyeva, 2018), systematized expertise and forecasts in the field of non-mortgage securitization (Suslov, 2015), as well as asset securitization in commercial organizations in general (Kovaleva, Khvostenko, Glukhova, Mozharovsky, 2018).

Works, reviewing foreign securitization experience, have helped to come up with the interim and final results of the study: B. Dave and Y. Kobayashi (Dave, Kobayashi, 2018), I. Krekoten (Krekoten, Svistun, Khudolii, 2018), C.Y.-P. Lo (Lo, 2018).

The study relies on the data from the analytical materials published on the official website of the Central Bank of the Russian Federation, on the website of the Federal Service of State Statistics of the Russian Federation, on the information portal Rusipoteka, rating agency Expert RA, and other materials.

The study applied a number of general scientific methods: a logical and retrospective analysis, synthesis, generalization, and system approach, expert evaluation method, visualization and correlation analysis involving the use of MS Excel.

The present study has been presented at the 12th International Conference "Economies of the Balkan and Eastern European Countries", EBEEC 2020, that has been online in Opatija, Croatia from May 29th to 31th 2020 (http://ebeec.ihu.gr).

\section{Data, Methodology and Empirical Results}

\subsection{Mortgage loans market in Russia}

The development of securitization in Russia began long before the introduction of legislation regulating the procedure of these transactions. Past this stage of development, the securitization market is starting to move towards growth and competition. Amendments to the current legislation in the field of non-mortgage securitization, a new procedure for assessing credit risk, together with the state support in the form of the Agency for Housing Mortgage Lending (AHML), which was transformed later into a financial housing development institution DOM.RF, and the State Development Corporation VEB.RF (former Vnesheconombank), have led to the increase in securitization in Russia. However, all these achievements do not guarantee the readiness of existing infrastructure. Under current conditions, the majority of securitization transactions are related to securitization of mortgage assets.

DOM.RF (until 2018 known as the Agency for Housing Mortgage Lending (AHML)) provides a mechanism for refinancing mortgage loans by issuing single-tranche mortgage bonds. It is expected that in 2019 the issuing volume will exceed 150 billion rubles. In 2018, the issuing volume of mortgage bonds amounted to more than 100 billion rubles and the transactions involved public and private banks: Sberbank, VTB, Raiffeisen bank, Housing Finance Bank. At the end of December 2017, a deal securitized the mortgage portfolio of VTB 24 by issuing mortgage bonds worth 48.2 billion rubles. Besides that, VTB accepted applications for the purchase of securities from institutional investors.

In 2018 the volume of deals reached 146 billion rubles. VTB planned to implement more transactions involving mortgage, consumer and auto loans in 2018, expecting a significant interest of local investors in auto loan securitization. This exactly what happened in November 2018. VTB together with DOM.RF (AHML) issued mortgage bonds worth 74.3 billion rubles.

In view of 2019, VTB signed a memorandum with DOM.RF to issue mortgage bonds of up to 500 billion rubles in $2019-2021$. Bonds will be secured by the pools of mortgages issued by the VTB Group and guaranteed by DOM.RF.

The first bond issuing within Vnesheconombank's Project Finance Factory was planned for the beginning of 2018. However, as of March 2018, the planned issuance was never carried out. 
The proposed mechanism involves risk distribution: at the first stage, the borrower receives a syndicated loan from several tranches, while the VEB assumes the role of a lending agent and pledge manager; at the second stage, bonds for the amount from 10 to 30 billion rubles, guaranteed by the government and secured by the tranche portfolio, are issued. The long-term tranche is initially financed by the VEB and then assigned to the bond issuer, a special purpose vehicle (SPV). Assets are accrued to bondholders of all issuances, with the nominal value of bonds issued at any time not exceeding the asset value. Experts plan that in three years' time the portfolio of SPV will increase to 300 billion rubles.

Mortgaging remains the most dynamic segment and one of the drivers of the Russian banking system. In 2016, when the volume of issued mortgages exceeded 1.5 trillion rubles, lending rates were at a historic low. In 2018 , mortgaging levels broke all records and exceeded the volume of 2016 by 2 times. As of December 31,2018 mortgage lending volumes reached 3 billion rubles (fig. 1 ).

These factors contribute to the development of mortgage securitization in Russia. However, the increase in the key rate led to the increase in the mortgage rate, which influenced the forecasts in mortgage lending volumes in 2019.

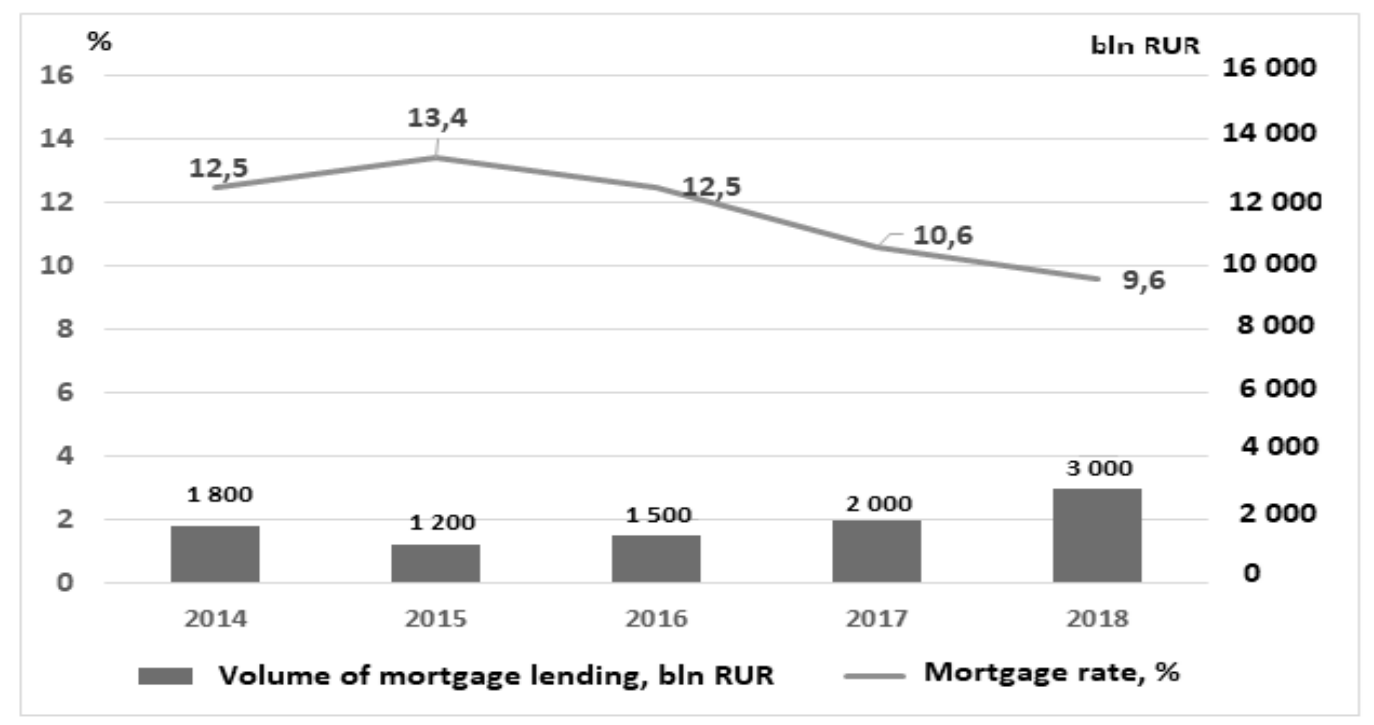

Figure 1: Dynamics of mortgaging in the Russian Federation

Note : Compiled by the author on the basis of data provided by the Central Bank of the Russian Federation. [Electronic resource]. URL: http://cbr.ru/analytics/bnksyst/ (accessed: 03.10.2019).

The Russian mortgage market is stable and has big prospects for further development: the share of mortgaging to GDP in Russia is only 5\% compared to the average $35 \%$ in other countries. Based on the projections of the researchers, more than 8 million families might be granted mortgages in the next 5 years, which is more than ever in the history of the mortgage market since 2004. At the same time, the events of 2020 allow us to judge that the forecasts are more than modest. With the outbreak of the COVID-19 pandemic, the government of the Russian Federation took a number of measures to support the economy during the period of self-isolation, one of which was aimed at supporting mortgage lending. In addition to the simplified scheme for obtaining these loans and the complete digitalization of procedures, interest rates on housing mortgage loans were reduced: according to preliminary estimates, the average market decline was $1.5 \%$. In addition, the so-called "mortgage holidays" and the opportunity to restructure loans were provided to families in difficult life situations due to the pandemic. All this gave a significant incentive to increase the volume of housing mortgage lending, which, according to the Bank of Russia, in January-July 2020 exceeded the volume of the same period in 2019 by $34.3 \%$. At present, mortgages issued by universal commercial banks are playing an increasing role. The Russian mortgage market consists of a large number of banks with mortgages in their balance sheets.

Based on the results of 2018 , it is possible to identify 10 banks as leaders in the Russian mortgage market (Table $1)$. 
Table 1: Performance of leading mortgage banks in Russia in 2018

\begin{tabular}{|c|c|c|c|c|}
\hline $\mathrm{N}$ & Bank & $\begin{array}{l}\text { The volume of } \\
\text { issued } \\
\text { mortgage loans, } \\
\text { mln rub. }\end{array}$ & $\begin{array}{l}\text { Number of issued } \\
\text { mortgages, pieces }\end{array}$ & $\begin{array}{l}\text { Increase in the volume } \\
\text { of issued loans } \\
\text { compared to } 2017, \%\end{array}$ \\
\hline $\mathrm{A}$ & 1 & 2 & 3 & 4 \\
\hline 1 & Sberbank & 1560204 & 827928 & 44 \\
\hline 2 & VTB & 672292 & 289898 & 55 \\
\hline 3 & Gazprombank & 149408 & 64283 & 87 \\
\hline 4 & $\begin{array}{l}\text { Russian Agricultural Bank } \\
\text { (Rosselkhozbank) }\end{array}$ & 128004 & 68138 & 75 \\
\hline 5 & CB DeltaCredit & 74643 & 28858 & 28 \\
\hline 6 & Raiffeisen bank & 63441 & 22761 & 7,6 \\
\hline 7 & Absolute Bank & 48096 & 19807 & 78 \\
\hline 8 & Otkritie Bank & 33743 & 13323 & 171 \\
\hline 9 & Alfa-Bank & 33049 & 9091 & no data \\
\hline 10 & Bank Uralsib & 30531 & 14168 & 13 \\
\hline
\end{tabular}

Note : Compiled by the author on the basis of the analytical material of LLC "Rusipoteka" - an overview of the competitive environment in the mortgage market in 2018. [Electronic source]. URL: http://www.ludiipoteki.ru/shop/researches/entry/826/ (accessed: 14.09.2019)

Sberbank of Russia headed the list of leading mortgage banks in 2018. The volume of home equity loans issued by Sberbank is 2.32 times higher than by VTB, which comes second in the list. If compared by the number of mortgages issued in the specified period, Sberbank exceeded VTB by 2.85 times. Other banks in the rating list showed lower volumes and the number of mortgages issued.

However, if we compare the same banks in 2017, almost all banks demonstrated a positive increase (from $7.6 \%$ to $171 \%$ ), which fact indicates the development of mortgaging and the emerging positive dynamics.

In order to understand the conditions of the mortgage market better, it is necessary to consider the share of banks, included in the list of TOP-10 mortgage institutions, in the total volume of mortgages issued in 2018 (fig. 2).

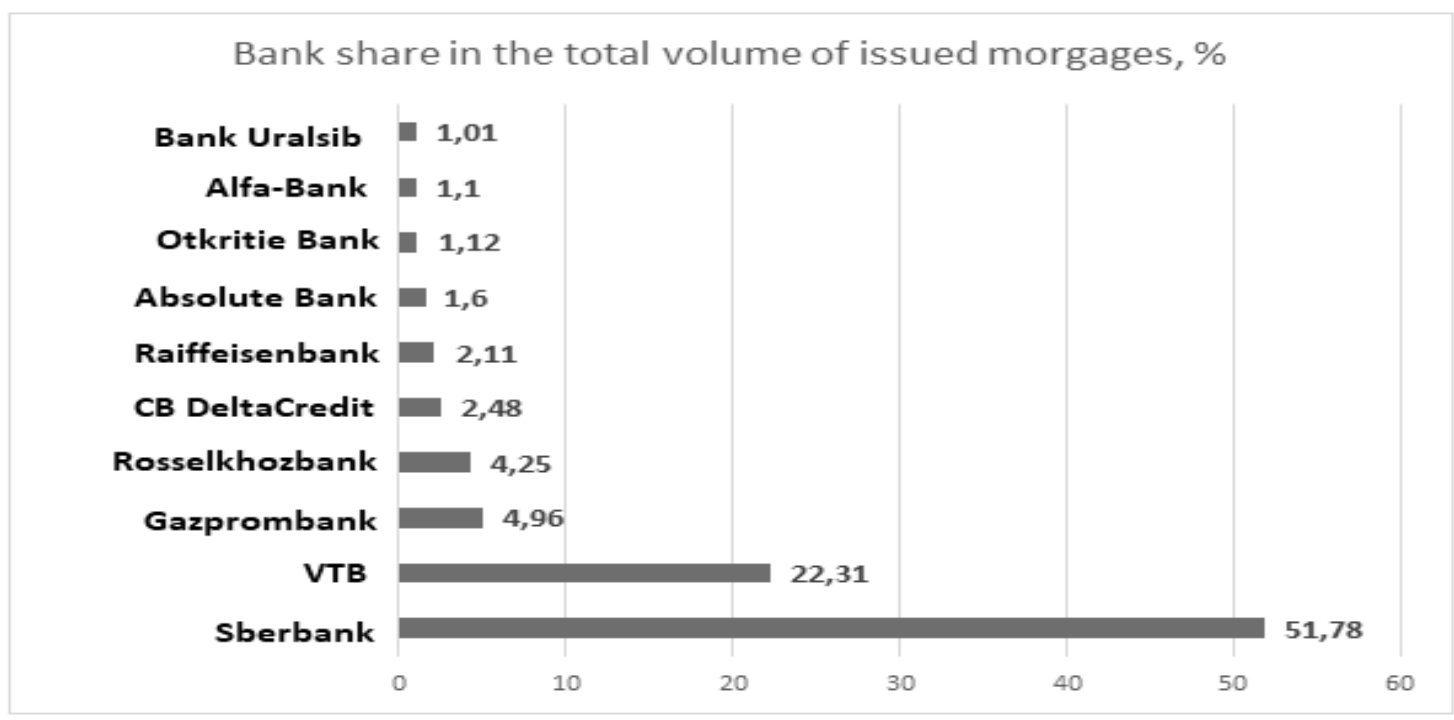

Figure 2: Share of leading banks in the total volume of mortgages issued in 2018

Note : Compiled by the author on the basis of the analytical material of LLC "Rusipoteka" - an overview of the competitive environment in the mortgage market in 2018. [Electronic source]. URL: http://www.ludiipoteki.ru/shop/researches/entry/826/ (accessed: 14.09.2019)

PJSC Sberbank $(51.78 \%)$ and VTB (22.31\%) became the absolute leaders in issuing mortgages with a total share of 74.09\%. They are followed by Gazprombank (4.96\%), Russian Agricultural Bank (4.25\%), CB DeltaCredit (2.48\%), and others.

A graph showing the volume of loans granted to residents in rubles in 2013 - 2018 (fig. 3) has been built in order to assess growth or decline trends in mortgage demand. At the end of 2018 , mortgage loans increased significantly in volume and number compared to the same period in 2015.

Over the period of 2012-2018, the volume of issued mortgages increased by 1,981,123 million rubles, or $192 \%$ at the end of 2018 compared to 2013 , which certainly confirms the positive forecast for mortgage lending. Such an active growth indicates that the demand for mortgage loans in Russia today is far from saturation: every year more families are granted mortgage loans. In 2018, their number almost reached 1.5 million, which is not so much for Russia. In addition, real estate is often viewed by Russians as a good investment. Therefore, people prefer this form of investment than others.

The dynamics of the volume of mortgage lending is affected by the devaluation of the Russian ruble, the rise in real estate prices, and some other factors. The growth rates of lending volumes are gradually decreasing. For 
example, the growth rate of the mortgage portfolio of the leader in terms of lending, Sberbank of Russia, is lower than that of its closest competitor VTB. This indicates a gradual cooling of the demand for mortgage loans, which in turn is taken into account in securitization. Not all mortgage loans are securitized, but only a share of the portfolio determined by the banks' policy. The slowdown in securitization is due to expectations of saturation of the mortgage market. And the first to feel such saturation is the market leader, Sberbank, which predetermines a decrease in the growth rate of the portfolio in comparison with VTB Bank.

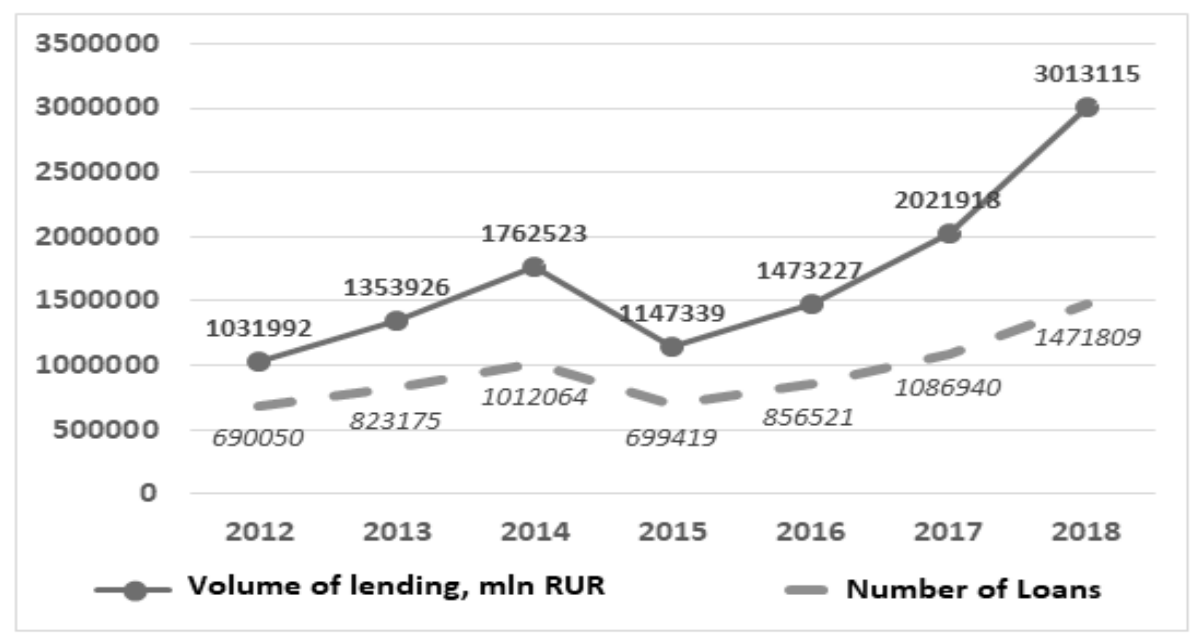

Figure 3: Volume and number of mortgages issued to individuals during the period of $2012-2018$.

Note : Compiled by the author on the basis of the analytical material of LLC "Rusipoteka" - the market overview of the mortgage market in $2012-$ 2018. [Electronic source]. URL: http://www.ludiipoteki.ru/shop/researches/entry (accessed: 24.09.2019)

\subsection{Development of mortgage securitization in Russia}

The growth in the Russian mortgage market could not but influence the development of the mortgage securitization market, with a growing number of transactions during the period of $2016-2018$ (fig. 4).

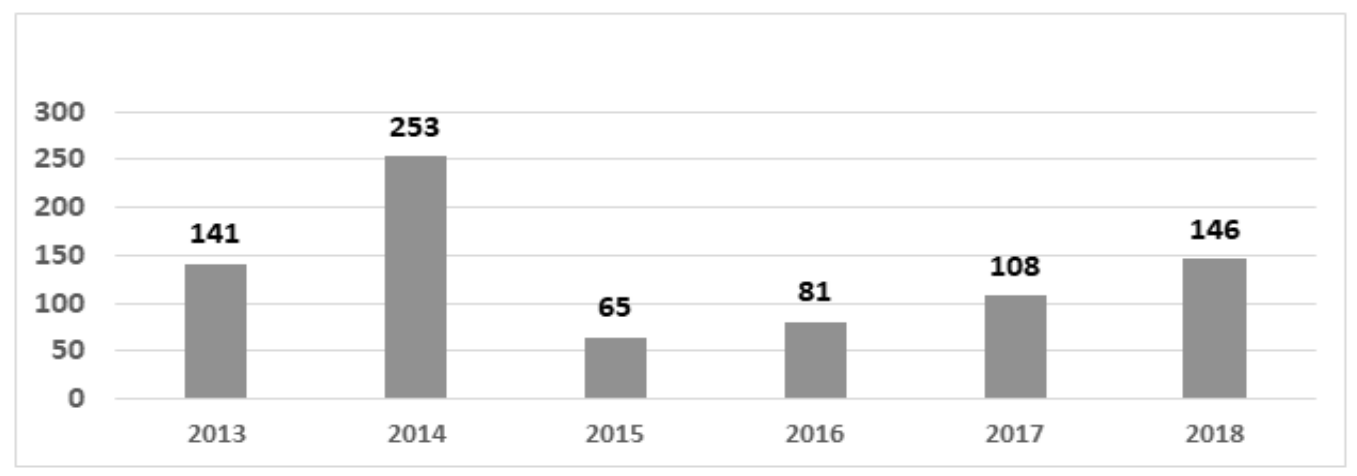

Figure 4: Mortgage securitization volumes in the Russian Federation, bln. rub.

Note : Compiled by the author on the basis of the analytical material of LLC "Rusipoteka" - the market overview of the mortgage market in 20132018. [Electronic source]. URL: http://www.ludiipoteki.ru/shop/researches/entry (accessed: 24.09.2019)

The crisis of 2014 led to a sharp $74 \%$ drop in mortgage securities. However, with the growth in the volume and amount of mortgage lending, there has been an increase in the securitization of mortgage assets. The development of this type of financing has also been pushed by the restrictions in foreign capital borrowing. Mortgage lending growth rates have become the main driver for the increase in mortgage securitization.

Public policies and government support have had a positive impact on the development of the mortgage market. Government programs aimed at increasing housing construction volumes and improving mortgage lending conditions include the program for housing renovation, the Federal Target Program "Housing" for 2015-2020, the priority project "Mortgage and rental housing" and provide data used to forecast trends in mortgage securitization.

In order to identify the nature and level of correlation, an elementary correlation analysis of the impact of the interest rate on the volumes of issued mortgages, presented in figures 5 (a) and (b), respectively, was carried out. The charts show a monthly change in indicators over a 10-year period.

Using a set of observations of the monthly dynamics of the weighted average interest rate on mortgage loans and monthly volumes of issued mortgages from the beginning of 2009 to the end of 2018 , the correlation coefficient was calculated using the CORREL function in MS Excel. The program calculates the coefficient according to Formula 1: 
where $\mathrm{n}$ - number of periods

$$
r=\frac{\sum_{i=1}^{n}\left(x_{i}-\bar{x}\right) *\left(y_{i}-\bar{y}\right)}{\sqrt{\sum_{i=1}^{n}\left(x_{i}-\bar{x}\right)^{2}} * \sqrt{\sum_{i=1}^{n}\left(y_{i}-\bar{y}\right)^{2}}}
$$

$x_{i}$ - amount of mortgage loans issued in period $\mathrm{i}$;

$\bar{x}$ - average value or issued mortgages over the entire period of observation;

$y_{i}$ - value of average weighted interest rate on mortgage loans in period i;

$\bar{y}$ - average value of average weighted interest rate on mortgage loans over the entire period of observation.

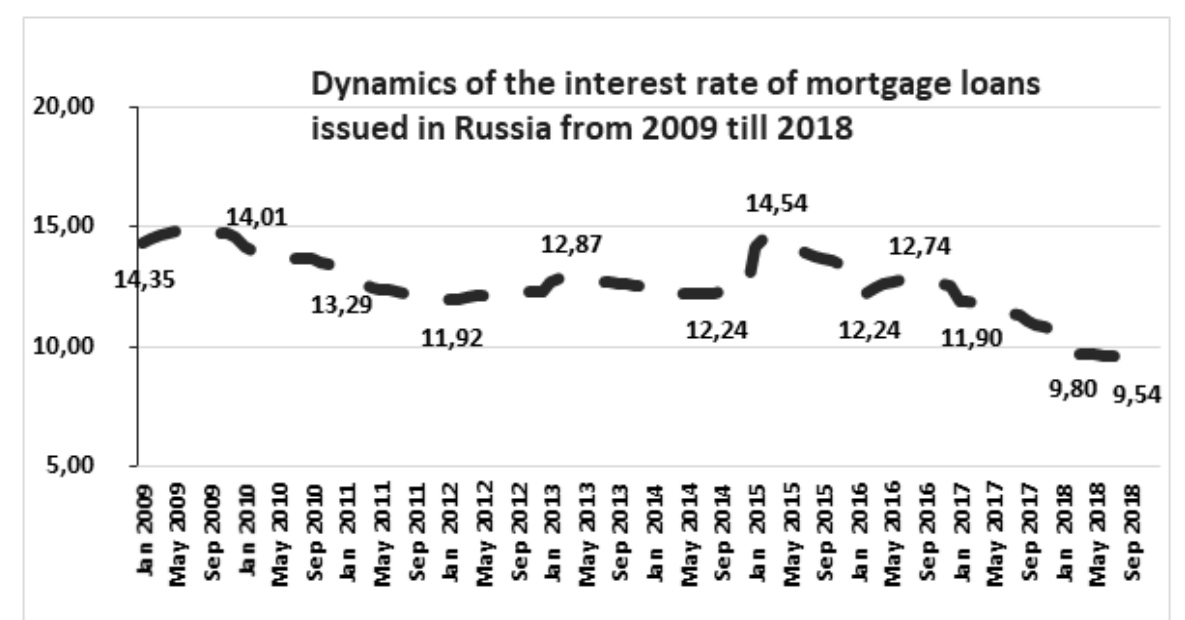

(a)

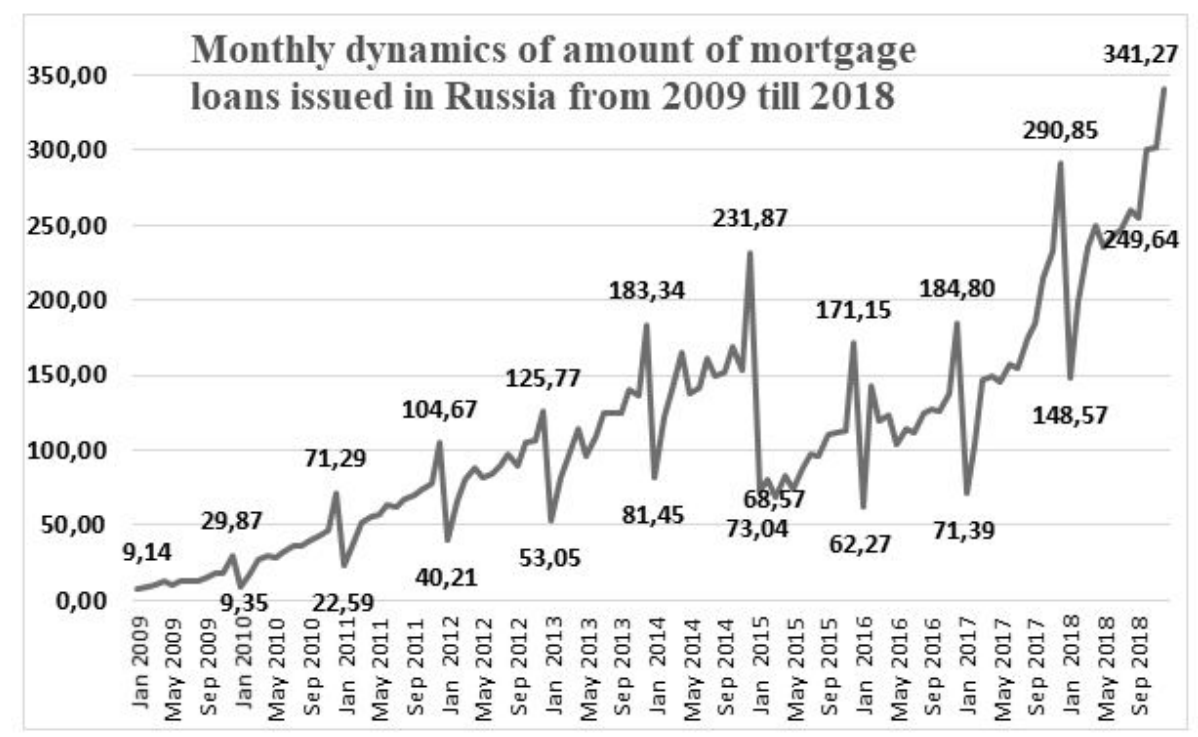

(b)

Figure 5: Monthly dynamics of interest rate and amount of mortgage loans issued in Russia from 1.01.2009 till 31.12.2018

Note : Compiled by the author on the basis of the analytical material of LLC "Rusipoteka" - the market overview of the mortgage market in 20092018. [Electronic source]. URL: http://www.ludiipoteki.ru/shop/researches/entry (accessed: 24.09.2019)

According to calculations, the correlation coefficient $r$ amounted to -0.829658207 , which indicates that there is a strong inverse dependence between the interest rate on loans and the amount of mortgages granted. That is, the reduction of mortgage loan rates results in the increases in the volume of their issuance and vice versa.

The assessment of the statistical significance of the correlation coefficient due to the small sample size was performed using the Student's t-test. The observed (actual) value of this criterion (4.6995) exceeds the critical values from the tables and is considered significant. Consequently, there is a close statistical relationship between the studied variables.

Coefficients of the linear function (Formula 2) are determined with the help of LINEST function in MS Excel:

$$
\mathbf{Y}=\mathbf{a x}+\mathbf{b}
$$

where $\mathrm{y}$ - amount of issued mortgage loans;

$\mathrm{x}$ - value of the average interest rate on a mortgage;

$\mathrm{a}, \mathrm{b}-$ linear function coefficients. 
Calculations result in the following equation (Formula 3):

$$
\mathrm{Y}=-44223.2 * \mathrm{X}+665700.1
$$

Linear function (Formula 3) makes it possible to determine the estimated value of all mortgage loans issued in 2018 and compare it with the real value of the same year (table 2 ).

Table 2: Difference between real and estimated mortgage values in 2018

\begin{tabular}{|l|l|l|l|}
\hline Date & $\begin{array}{l}\text { Real value of mortgage } \\
\text { loans over the period, mln. } \\
\text { rub. }\end{array}$ & $\begin{array}{l}\text { Estimated value of } \\
\text { mortgage loans over the } \\
\text { period, mln. rub. }\end{array}$ & $\begin{array}{l}\text { Difference between real } \\
\text { and estimated values, mln. } \\
\text { rub. }\end{array}$ \\
\hline January 2018 & 148573 & 230101.1 & -81528 \\
\hline February 2018 & 199261 & 232312.3 & -33051 \\
\hline March 2018 & 235307 & 234965.7 & 341 \\
\hline April 2018 & 249641 & 237176.9 & 12464 \\
\hline May 2018 & 235846 & 238503.6 & -2658 \\
\hline June 2018 & 243060 & 239830.2 & 3230 \\
\hline July 2018 & 246801 & 240272.5 & 6529 \\
\hline August 2018 & 260302 & 241599.2 & 18703 \\
\hline September 2018 & 255354 & 242483.6 & 12870 \\
\hline October 2018 & 300572 & 243368.1 & 57204 \\
\hline November 2018 & 302174 & 242925.9 & 58364 \\
\hline December 2018 & 341265 & 2867349 & 98339 \\
\hline Total in 2018 & 3018156 & 150807 \\
\hline
\end{tabular}

Note : Compiled by the author on the basis of the analytical material of LLC "Rusipoteka" - the market overview of the mortgage market in 20132018. [Electronic source]. URL: http://www.ludiipoteki.ru/shop/researches/entry (accessed: 24.09.2019)

Estimated volume of mortgage loans exceeded the real volume in January, February and May, which could have been connected with a decrease in the activity of buyers during long holidays. The difference between the calculated indicator and the real one had been increasing in the period from June to December 2018, which could be explained by the cumulative or "snowball" effect. On the whole, in 2018, the estimated volume of mortgage lending was 150.8 billion rubles less than the real one. This fact is the evidence of the correct economic policy in the field of mortgage lending, government support and regulation of the key rate of the Central Bank. These measures proved to be quite efficient in attracting new borrowers and increasing the mortgage portfolio in excess of the estimated figures. The figure of 150.8 billion rubles are those extra resources that banks did not expect.

Since mortgage securitization is recognized as the most developed in the Russian Federation, it is necessary to estimate the impact of these additional financial resources on the securitized mortgage portfolio. For this purpose, it is necessary to calculate the securitized mortgage portfolio ratio in the total amount of issued mortgage. The securitization coefficient shall be calculated in accordance with the following formula (Formula 4):

$$
\frac{\sum_{i=1}^{n} x_{i} / n}{\sum_{i=1}^{n} y_{i} / n} * 100 \%
$$

where $\mathrm{n}$ - number of observation periods,

$x_{i}$ - volume of securitized mortgage portfolio in period n;

$y_{i}$ - volume of all mortgage portfolio in period $n$.

The calculation is based on annual data for 2013-2018. After summing it up, the securitization coefficient equals to $8.9606 \%$. In other words, only $8.96 \%$ of the entire mortgage loan portfolio is securitized. On the one hand, the value is not high, but on the other hand, the share of the securitized portfolio has the potential to grow as a result of the competent financial policy.

The amount of "additional securitization", the part of the securitized portfolio, which formed as a result of the difference between the volume of issued mortgage loans and the estimated one, is of particular interest. In order to assess it, it is necessary to multiply the difference between the actual amount of the mortgage portfolio and the estimated one by the securitization coefficient. Thus, the increase in securitization due to the government's quality mortgage lending policy in 2018 amounted to 13.513 million rubles. This is $9.26 \%$ of the total securitization (146 billion rubles) in 2018. Therefore, the state, by introducing changes in the socially important sector of the economy, indirectly increased the volume of securitized securities, which has a positive impact on the growth of the industry as a whole.

\subsection{Development of non-mortgage securitization in Russia}

Exploring the issues of non-mortgage securitization, those authors (Kharchenko, 2017), whose studies concern its international aspects, note that asset-backed securities (ABS) occupy a significant share of the international debt market, with the main instruments including bonds for auto loans, credit cards and student loans. 
Today, bonds secured by auto loans may become another instrument of the securitization market in Russia, in addition to mortgage lending. However, there are certain difficulties, including duration assessment and low liquidity, which may limit the interest of investors. In addition, in 2014 some legal restrictions were imposed on the Russian non-mortgage securitization market. All transactions prior to the adoption of amendments to the legislation introduced by the Federal Law No. 379-FZ were carried out in accordance with the legislation of the country where the SPV was established, among which were Cyprus, Great Britain, Spain, Portugal and Italy.

The first transaction under Russian law included placement of bonds secured by the auto loan portfolio in June 2015 for the amount of more than 12.5 billion rubles. The originator of the transaction, i.e. the entity that has the right to assign receivables during the securitization of assets, was Credit Europe Bank. It was the first securitization transaction to settle open accounts between several banks, to check the complex procedure of the guarantee pool replenishment ("revolver"), to develop a mechanism for accelerated depreciation of bonds to meet specific conditions in tender documents and a unified system to control compliance with the main parameters of the transaction. The dynamics of non-mortgage securitization in Russia is unstable (fig. 6), and the data are still insufficient for relevant forecasting.

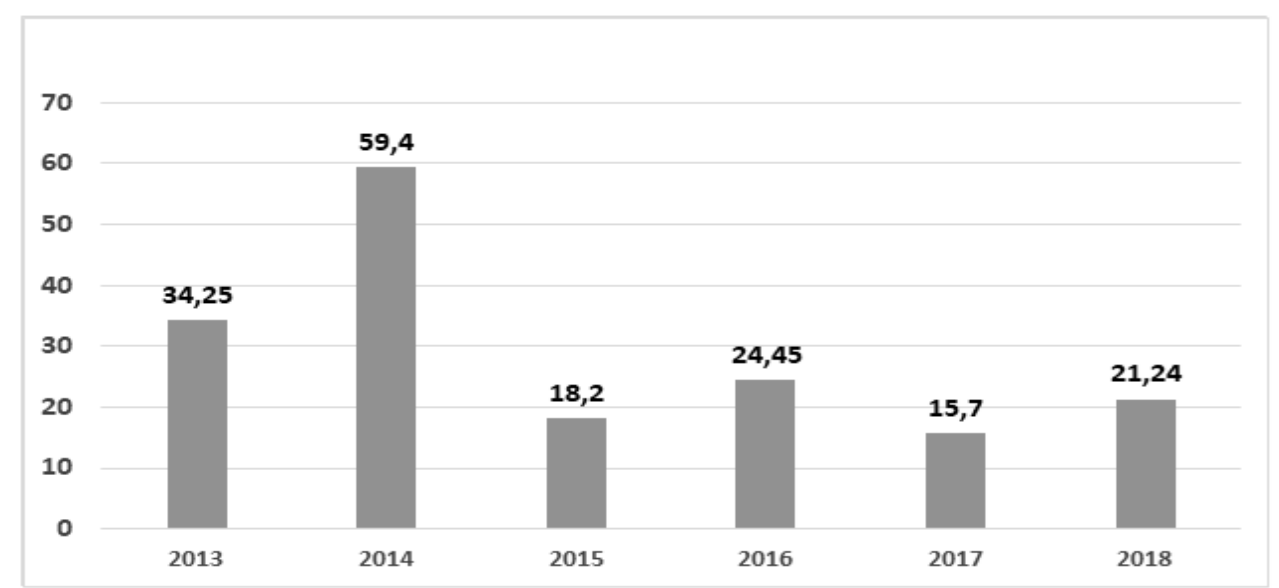

Figure 6 - Dynamics of non-mortgage securitization in Russia, bln rub.

Note : Compiled by the author on the basis of the analytical material of LLC "Rusipoteka" - the bank financial data. [Electronic source〕. URL: http://www.ludiipoteki.ru/shop/researches/entry/975/ (accessed: 1.10.2019)

The most successful year for non-mortgage lending and securitization was 2014. After the crisis in December 2014, ABS securitization decreased by $69 \%$. In this case, correlation analysis will prove inaccurate due to the heterogeneity of assets underlying the non-mortgage securitization, as well as due to the lack of statistical data for the reliable calculation of indicators.

One of the reasons for the low securitization of non-mortgage assets compared to mortgage-backed securities (MBS) is undeveloped legislation. Another reason is the lack of understanding of the duration of this instrument: it is hard to predict how the underlying loans will be depreciated. Therefore, while in the West such instruments are of increasing interest to insurance companies and other institutionalized investors, in Russia there are no tools to hedge the risks. It can be concluded that the Russian Federation as a whole does not have an established market of such investors who are ready to invest in these instruments. Low liquidity on such securities also inhibits the development of non-mortgage securitization.

The high cost of the securitization process also hinders the development of the market. Securitization becomes profitable with a portfolio of 3.000 million rubles or more. According to various estimates, the cost of preparing the transaction ranges from 30 to 45 million rubles, and most of the costs are accounted for by consulting. At the same time, it is obvious that the costs of the initial issuance may be much higher due to the lack of experience. Thus, only large organizations seem to have access to this method of financing.

Thus, the growth of the securitization market undoubtedly has a direct correlation with the growth of the bank's loan portfolios. After a bad year in 2015, the mortgage and other lending markets are returning to pre-crisis indicators. On the one hand, it contributes to the development of securitization and financial market of the country as a whole. However, not all segments of loan portfolios are equally attractive to investors or have similar prospects for securitization

\subsection{Current problems of asset-backed securitization in Russia and their solutions}

The mechanism of attracting funds through asset securitization is widely used in the global financial market. Recently, this method of financing has reached emerging markets. Securitization allows a company to get a higher rating than the borrower's company, separating securitized assets from other assets of the organization and thereby reducing the cost of borrowed funds. This method of financing has other advantages (Aksenov and Golikov, 2013).

The current attractiveness of securitization operations for Russian banks might be explained by the following:

Russian banks face a long-term liquidity deficit. Securitization makes it possible to attract long-term and relatively inexpensive capital, in particular, from pension funds. 
The ability of commercial banks to diversify their funding sources is important in managing liquidity and interest rate risks.

Securitization is a convenient way to control liquidity risks on the balance sheet as securities are more liquid than long-term loans.

State corporations and institutions contribute to the development of the securitization market.

There is a demand for securities from investors.

The main problem for the development of securitization in our country before 2014 was the absence of laws regulating the process of asset securitization. The only statutory instrument was the law on the securitization of mortgage loans (Federal Law No. 152-FZ of 11 November 2003 "On mortgage-backed securities"). Securitization of other non-mortgage assets under Russian law is currently regulated by Federal Law No. 379-FZ of July 1, 2014, as amended on July 3, 2016. However, insufficient regulatory provisions still affect the volume of non-mortgage securitization transactions (Kharchenko, 2017).

At the moment, one of the main problems of securitization in Russia is the lack of and inability to attract longterm resources in the international market. In this regard, the state needs to take measures to transform legislation in the field of securitization. The new law should reflect the statements, put forward by major market players, and stimulate investments in securitized assets by institutional investors. It is also necessary to make provisions for the measures designed, on the one hand, to encourage banks to resort to securitization and, on the other hand, to take into account the foreign experience of securitization, which restrains the so-called "bubbles" in the derivatives markets.

Another way to increase securitization in Russia is to standardize assets. Standardization greatly simplifies securitization. Standardized assets are easier to pool, which significantly reduces costs. On the other hand, standardized assets make it easier to conduct the analysis and assessment of collateral securities and risks for such assets, which facilitates decision-making by investors and, therefore, increases the attractiveness of securitized securities (Kolmykova, 2013).

DOM.RF is involved in the buyout and standardization of mortgage loans. However, its limited functionality also hinders the development of securitization. It is necessary to extend the mandate of the company and broaden its functions. For example, in order to reduce systemic risks of the mortgage market, DOM.RF shall provide information on the default of groups of borrowers. Since the mortgage portfolio of DOM.RF is the largest in the market and welldiversified at the regional level, this information will allow major lenders to improve the quality of borrower assessment and risk forecasting for the developing portfolio.

Mortgage loans should rightly be the pioneers of securitization. In order to consolidate this position, the professional community, for example, in the form of domestic banking associations, should develop general principles for the organization of a pool of standardized assets and create standard rules for the issue of securities and their placement. At the same time, it is necessary to avoid totalitarian actions. All processes should be regulated by market conditions, without the interference of the government and the regulator in pricing at any stage, i.e. at the stage of formation of the pool of assets, and at the stage of securitization.

Difficulties also lie in the absence of coordination of actions and lack of trust in new developments. Many banks, together with financial companies and some public authorities, make attempts at developing the mortgage market in the digital environment. Information technology has been helping to improve various aspects of life for 40 years and has been in use in banks for more than 15 years. The development of banking applications and technologies facilitates the lives of clients, as well as bank employees. For instance, in the middle of 2018, the legislators passed amendments, making provisions for the electronic mortgage deed, which significantly simplified its storage. Following these amendments, there have been introduced various services to provide mortgage loans via the Internet. As a result of these measures, the speed of the transactions is expected to increase from 2 weeks to 3-4 days. This is only the first stage in the process and, obviously, the incompetence of people, abuse of powers or even criminal actions might pose obstacles and impede the development of new products. Besides, not all clients are ready to conduct online transactions. Hopefully, there will be improvements in cybersecurity, investigation of crimes related to the use of electronic signatures, protection of the rights of customers of banks involved in online banking, and customers will be given time to adapt to new technologies.

The development of new financial products and technologies often runs ahead of the expectations of society, which is not always prepared to accept them. Moreover, even financial service providers might not be ready. One example is the project of a "decentralized depository system" based on the MasterChain platform that was developed by banks and financial companies. It is a very convenient and progressive tool to accelerate the processes of registration, storage, and transfer of the title to real estate. However, at present, the platform operates only with mortgages and, thus, promotes only mortgage lending. In order to develop securitization, it is necessary for the platform to be able to transfer and register titles, which is not yet in the power of the banks and financial companies. In order to meet the real needs of the securitization market, the involvement of the Federal Service for State Registration, the Cadastre, and Cartography (Rosreestr) is necessary. As soon as the agency starts registering titles and transferring mortgages using blockchain technology, the process of transferring mortgages will be accelerated and the process of creating mortgage pools will also gain speed. It will reduce the time of the securitization process and, consequently, the costs of issuing securitization securities, which may facilitate the entry of small and medium-sized banks into the market. This will not only promote long-term liquidity and asset portfolio expansion, but also the development of interbank competition.

The next problem is bureaucratic inconsistencies. According to the Bank of Russia's Information of 15 July 2018 "On setting the long-term creditworthiness rating to invest pension savings and savings for housing provision for servicemen", the minimum rating level for investing pension savings is set at BB+ as (RU) in the classification of 
Analytical Credit Rating Agency (ACRA JSC). However, in accordance with the guidelines of the Basel Committee on Banking Supervision on structured finance instruments, including mortgage-backed securities, the agency assigned the suffix ".SF" (i.e. it should read not just RU, but RU.SF). Contrary to expectations, that was not a formality and it would now require a separate decision of the regulator to determine the minimum rating level for mortgage-backed securities to invest pension savings (RUSIPOTECA, 2019)1.

Many authors (Aksenov, Golikov, 2013; Denisov, 2016) believe that for the development of securitization it is important to abolish the $10 \%$ limit in the portfolio for investing pension savings of non-governmental pension funds (NPFs) in mortgage-backed securities, which fall under this restriction due to the specifics of depreciation. The reasoning is usually based on the fact that the credit quality of such securities meets the requirements of NPF investments. In addition, the NPF managers have sufficient expertise and resources to evaluate such securities. However, the $10-15 \%$ limit seems to be fair and corresponds to the moderate investment policy that a socially significant institutional investor should follow. Other institutional investors, including investment funds and insurance companies, might adopt more aggressive investment strategies to expand their investor base.

Solving the above problems will undoubtedly contribute to the development of the domestic asset securitization market. Changes in the regulatory framework and standardization of transactions will promote further growth of the Russian mortgage market and create additional incentives for housing construction, as well as reduce the degree of monopolization in the mortgage segment of the Russian economy. The proposed measures will also enhance investor protection in the Russian real estate market and securitize transactions.

\section{Conclusion}

Based on the analysis of the current state of the securitization market in Russia, mortgage securitization obviously prevails. This is due to the fact that mortgage loans are long-term and mostly standardized, which facilitates the securitization process. The government policy in the sphere of mortgage lending also contributes to this process. The state, while managing the change in the socially important sector of the economy, indirectly increased the volume of securitized securities, which had a positive impact on the whole industry. In the article, it was proved that housing mortgage lending is showing steady growth, which is supported by successful government policies. Other types of mortgage lending are not developing yet.

The non-mortgage securitization has a much smaller share in the total volume of securitization. This can be accounted for by the lack of experience in conducting transactions and standardization of assets, as well as by insufficient attention of the government to this type of securitization. Undoubtedly, direct and indirect government support is fully aimed at mortgage securitization.

The securitization process, in general, is not devoid of the problems hindering its development. For example, there are inconsistencies in the legislation. Besides, the sanctions imposed by the USA and European countries do not allow foreign investors to invest funds in the securities of leading Russian issuers. Particular attention should be paid to bureaucratic inconsistencies that require a separate decision of the regulator to determine the minimum rating level of mortgage-backed securities for the investment of pension savings.

National financial technologies in the field of mortgage securitization might have become the most advanced in the world by the present time. However, in order to satisfy all the requirements set for transactions and to meet the real demands of the securitization market, it is necessary to involve the Federal Service for State Registration, the Cadastre, and Cartography ("Rosreestre"). The agency shall include the blockchain technology in the arsenal of tools to speed up the registration of rights and transfer of mortgages, which in its turn will facilitate the formation of mortgage pools, making securitization cheaper and more accessible for smaller banks.

To encourage customers to use digital technology, banks and public service providers need to pay attention to cybersecurity. Law enforcement agencies should consolidate their efforts to investigate electronic signature-related crimes, protect the rights of online banking customers, and promote and raise public awareness.

\section{References}

Aksenov V.S. et al, 2013. Problems and prospects of assets securitization in the modern Russian economy. Herald of the RSUH. Series: Economics. Management. Law, No.15(116), pp 151-158. (in Russian).

Aleksandrova N.V., 2007. Concept and types of asset-backed securitization. Finance and credit, No.5 (245). [Electronic access]. URL: https://cyberleninka.ru/article/n/ponyatie-i-vidy-sekyuritizatsii-aktivov (accessed: 20.03.2019). (In Russian)

Bar H.P. et al, 2007. Asset Securitisation: Securitisation of Financial Assets - Innovative Technology of Banks Funding. Moscow, Wolters Kluwer, the Russian Federation. (in Russian)

Belikov T., 2009. Minefields of project financing: survival allowance for loan officers and investors. Moscow, Alpina Business Books, the Russian Federation. (in Russian)

Burkova Y.A., 2014. Main differences between real estate investment in Russia and abroad. Financial business, No. 5, pp 48-53. (In Russian)

Guliev I.I., 2014. Methods and models of the assessment of strategic investment projects. Issues of economics and law, No 9, pp 50-54. (In Russian)

\footnotetext{
${ }^{1}$ RUSIPOTEKA JSC, Encyclopedia of Russian securitization 2019. St Petersburg, 2019, p.62.
} 
Denisov M.A., 2016. Asset-backed securitization market in the Russian Federation: instruments, state, and specifics. Vestnik of NGUEU, No 2, pp 200-209. (In Russian)

Davidson E. et al, 2007. Mortgage securitization: global experience, structuring and analysis. Moscow, Vershina, the Russian Federation. (in Russian)

Drobishevskaia L. N. et al, 2013. Main participants and stages of securitization of financial assets. Economics space, No 3-2. [Electronic access]. URL: https://cyberleninka.ru/article/n/osnovnye-uchastniki-i-etapy-sekyuritizatsii-finansovyh-aktivov (accessed: 20.03.2019).

Dave B. et al, 2018. China's silk road economic belt initiative in central Asia: economic and security implications. Asia Europe Journal, Vol. 16, No 3, pp 267-281.

Golaido I.M. et al, 2019. Mortgage Lending in Russia: Problems and Prospects. OrelSIET bulletin, No 2 (48), pp 146-153. (In Russian)

Kharchenko, L.P., 2017. Convertible securities and structured receipts: hybrid instruments for issuers and investors. Technological Perspective within the Eurasian Space: New Markets and Points of Economic Growth Materials of the 3rd International Scientific Conference. St Petersburg, Russia, pp. 191-195. (In Russian)

Khmyz O.V. et al, 2018. Contemporary phase of securitization in the Russian Federation. Espacios, Vol. 39, No 36.

Kolmykova T.S., 2013. Investment analysis. Moscow, Infra-M, the Russian Federation. (in Russian)

Kovaleva T.M. et al, 2018. Actual problems of assets securitization in commercial organizations. Espacios, Vol. 39, No 22 , p. 28.

Krolivetskaia V.E.. 2019. Features of the new state of securitization in Russia. St Petersburg Economic Journal, No 1, pp 130-135.

Krekoten I. et al, 2018. Prospects of using security mechanisms in the process of rehabilitation the building sphere in Ukraine. International Journal of Engineering and Technology(UAE), Vol. 7, No 3, pp 219-224.

Lo C.Y.-P., 2018. Securitising HIV/AIDS: a game changer in state-societal relations in China. Globalization and Health, Vol. 14, No $1, \mathrm{p} 50$.

Rusipoteka JSC, 2019. Encyclopedia of Russian securitization. St Petersburg, the Russian Federation. (in Russian)

Suslov R., 2015. Non-mortgage securitization in Russia: is there future? Law and surveillance, No 1 (3), pp 20-24. (In Russian)

Vasilieva, E., 2018. Perspective trends in financing of housing-and-communal services. MATEC Web of Conferences. Series "International Science Conference SPbWOSCE-2017 "Business Technologies for Sustainable Urban Development". St Petersburg, Russia, p. 01050.

Yescombe E.R., 2013. Principles of project finance. 2nd ed., USA: Academic Press, USA.

This is an Open Access article distributed under the terms of the Creative Commons Attribution Licence 